\title{
Peran Atribut Destinasi Terhadap Pembentukan Citra Kota Bandung Sebagai Destinasi MICE di Indonesia
}

\author{
Marsianus Raga* \\ Sekolah Tinggi Pariwisata Bandung, Indonesia \\ Email: marsianusraga@stp-bandung.ac.id
}

\begin{abstract}
Meeting, Incentive, Conference and Exhibition/MICE business) continues to grow over time. Every country continues to strive to develop the MICE destination attributes such as affordability in terms of price/cost, tourist attractions, accessibility, amenity, activity and accountability possessed by the city. The purpose of this study was to research the response of the respondents (members of Asosiasi Perusahaan Pameran Indonesia/ASPERAPI) regarding Bandung destination attributes and image as MICE destinations and to examine the role or influence of destination attributes on forming Bandung city image as a MICE destination in Indonesia. This study uses multiple regression analysis to test the first classical assumption, the next multiple regression analysis which includes $\mathrm{T}$ test and $\mathrm{F}$ test analysis to examine the spatial relationship each variables of attributes destination to image variable and simultaneous relationship between destination attributes variable with image variable. The results of descriptive data processing the destination attributes and the image ofthe city of Bandung in good category. The results ofT test and $\mathrm{F}$ test showed that the affordability and activity have no significant effect on forming the image Bandung city as MICE destination. All attributes simultaneously effect on forming image of Bandung city as a MICE destination. The influence of destination attributes variable on forming image ofthe city of Bandung was $88.4 \%$, while the remaining $11.6 \%$ is influenced by other factors not observed. The availability of destination attributes with the best quality and quantity in Bandung will enhance the image of Bandung city as a MICE destination.
\end{abstract}

Keywords: Destination Attributes, MICE Destination Image

Abstrak

Rapat, Insentif, Konferensi, dan Pameran / bisnis MICE) terus berkembang seiring berjalannya waktu. Setiap negara terus berupaya mengembangkan atribut tujuan MICE seperti keterjangkauan dalam hal harga / biaya, tempat wisata, aksesibilitas, kemudahan, aktivitas, dan akuntabilitas yang dimiliki oleh kota. Tujuan dari penelitian ini adalah untuk meneliti respon responden (anggota Asosiasi Perusahaan Pameran Indonesia / ASPERAPI) mengenai atribut dan citra tujuan Bandung sebagai tujuan MICE dan untuk menguji peran atau pengaruh atribut tujuan pada pembentukan citra kota Bandung sebagai MICE tujuan di Indonesia. Penelitian ini menggunakan analisis regresi berganda untuk menguji asumsi klasik pertama, analisis regresi berganda berikutnya yang meliputi uji $\mathrm{T}$ dan analisis uji $\mathrm{F}$ untuk menguji hubungan spasial masing-masing variabel atribut tujuan terhadap variabel citra dan hubungan simultan antara variabel atribut tujuan dengan variabel citra. Hasil pengolahan data deskriptif, atribut tujuan dan citra kota Bandung dalam kategori baik. Hasil uji T dan uji $\mathrm{F}$ menunjukkan bahwa keterjangkauan dan aktivitas tidak berpengaruh signifikan terhadap pembentukan citra Kota Bandung sebagai tujuan MICE. Semua atribut secara simultan berpengaruh pada pembentukan citra kota Bandung sebagai tujuan MICE. Pengaruh variabel atribut destinasi terhadap pembentukan citra kota Bandung adalah 88,4\%, sedangkan sisanya $11,6 \%$ dipengaruhi oleh faktor lain yang tidak diamati. Ketersediaan atribut tujuan dengan kualitas dan kuantitas terbaik di Bandung akan meningkatkan citra kota Bandung sebagai tujuan MICE.

Kata kunci: Atribut Tujuan, Gambar Tujuan MICE

\section{A. PENDAHULUAN}

Bisnis pariwisata saat ini berkembang secara baik dan cenderung meningkat dari tahun kc tahun. United Nation-World Tourism Organization (UN-WTO) memberikan pandangan positif tentang pariwisata sebagai lumciuntuk pembangunan, kemakmuran dan kesejahteraan.Perjalanan wisata MICE termasuk

* Corresponding author

Received: January 01, 2019; Revised: March 01, 2019; Accepted: June 01, 2019 
dalam perjalanan wisata dengan tujuan bisnis dan profesional. Akronim MICE sudah mulai dikenal secara luas oleh masyarakat, yang menurut Rogers (2003.15), MICE merupakan terminologi yang digunakan untuk Meeting (pertemuan), Incentive (perjalaan insentif), Conference (konferensi)dan Exhibition. (pameran).

Bandung merupakan salah satu kota tujuan wisata MICE yang sudah ditetapkan olch Kementerian Pariwisata Dan Ekonomi Kreatif. Pemilihan sebuah destinasi oleh seorang wisatawan, termasuk wisatawan MICE sering dipengaruhi oleh push and pull factors. (Crompton, 1979; Kim, Lee, \& Klenosky, 2003; Klenosky. 2002),

Rittichainuwat. 2008). Push factors mengacu kepada motivasi dari wisatawan misalnya adanya kebutuhan untuk keluar dari kesibukan sehari-hari, adanya keinginan untuk berinteraksi dengan sesama. Sedangkan pull factor berhubungan dengan faktor - faktor yang mempengaruhi seseorang, kapan, di mana dan bagaimana orang melakukan perjalanan, termasuk untuk menghadiri sebuah kegiatan perjalanan wisata bisnis khususnya wisata MICE yang erat kaitannya dengan tampilan dari faktor penampilan, atraksi wisata dan atribut dari destinasi itu sendiri ((Klenosky, 2002).

Menurut Chiu\& Ananzeh (2012) yang mengutip pendapat dari Go \& Govers (1999); Kim \& Kim (2003); Kang, Suh, \& Jo (2005); Lee \& Back,(2005, 2007) bahwaatribut destinasi MICE terdiri dari affordability/keterjangkauan dalam hal harga, attractionlatraksi wisata, - accessibility/aksesibilitas, amenity/amenitas, aktivitas dan accountability/akuntabilitas. Selain peran atribut destinasi sebaga salah satu faktor penarik bagi organizer untuk menyelenggarakan sebuah kegiatan di suatu tempat atau kota, atribut destinasi juga dapat membentuk citra sebuah destinasi penyelenggaraan sebuah kegiatan MICE. Dalam hal pentingnya atribut destinasi dalam membentuk citra sebuah destinasi telah dilakukan studi oleh beberapa ahli seperti Oppermann, (1996a, 1996b), Go, Govers, 1999) pernah melakukan studi sudah dilakukan dan membuktikan tentang pentingnya sebuah atribut destinasi MICE dan diteruskan oleh Lee and Back (2007) yang melakukan pengujian tentang peran dari atribut destinasi MICE dalam membentuk keseluruhan citra dari destinasi. Sedangkan Citra dapat didefenisikan sebagai sebuah fenomena perscpsi yang, dibentuk mclalui alasan dari konsumen dan interpretasi emosi konsumen yang mana memiliki komponen kognitif (pengetahuan, keyakinan) dan afektif (perasaan). (Konecnik, 2004).

Komponen dari citra destinasi dalam aspek citra kognitif yang diadaptasi dari Chiu \& Ananzeh (2012) terdiri dari pengetahuan dari wisatawan/ organizer mengenai suasana, faktor politik dan sosial, fasilitas untuk wisatawan, sumber daya alam, infrastruktur umum, faktor ekonomi dan budaya (Beerli \& Martin, 2004a, 2004b; Ecthner \& Ritchie, 1993, 2003; McCartney, Butler \& Bennett, 2009, Schneider \& Sonmez, 1999). Sedangkan aspek citra afektif terdiri dari perasaan bersemangat-tidak bersemangat, perasaan menyenangkan-tidak menyenangkan, perasaan exiting-membosankan dan perasaan santaimembuat tertekan (Beerli \& Martin, 2004a, 2004b; Baloglu \& Love, 2005; Baloglu \& McCleary, 1999).

Selain peran atribut destinasi sebagai salah satu faktor penarik bagi organizer untuk menyelenggarakan sebuah kegiatan di suatu tempat atau kota, atribut destinasi juga dapat membentuk citra sebuah destinasi penyelenggaraan sebuah kegiatan MICE. Dalam hal pentingnya atribut destinasi dalam membentuk citra sebuah destinasi telah dilakukan studi oleh beberapa ahli seperti Oppermann, (1996a, 1996b), Go, Govers, 1999) pernah melakukan studi sudah dilakukan dan membuktikan tentang pentingnya sebuah atribut destinasi MICE dan diteruskan oleh Lee and Back (2007) yang melakukan pengujian tentang peran dari atribut destinasi MICE dalam membentuk keseluruhan citra dari destinasi. Sedangkan Citra dapat didefinisikan sebagai sebuah fenomena persepsi yang dibentuk melalui alasan dari konsumen dan interpretasi emosi konsumen yang mana memiliki komponen kognitif (pengetahuan, keyakinan) dan afektif (perasaan). (Konecnik, 2004). 
Beberapa penclitian sudah dilakukan untuk mengukur citra dari sebuah destinasi dan hal ini sangat tidak mudah untuk dilakukan karena melibatkan komponen yang bisa terlihat seperti aspek fisik, keadaan geografi, panorama, fasilitas untuk wisatawan, iklirn, tapi juga melibatkan aspek emosi dari wisatawan atau orang dijadikan sebagai narasumber untuk menilai citra scbuah destinasi. Dalam penelitian ini, komponen dari citra destinasi dalam aspek citra kognitif yang diadaptasi dari Chiu \& Ananzeh (2012) terdiri dari pengetahuan dari wisatawan/ organizer mengenai suasana, faktor politik dan sosial, fasilitas untuk wisatawan, sumber daya alam, infrastruktur umum, faktor ekonomi dan budaya (Beerli \& Martin, 2004a, 2004b; Ecthner \& Ritchie, 1993, 2003; McCartney, Butler \& Bennett, 2009, Schneider \& Sonmez, 1999). Sedangkan aspek citra afektif terdiri dari perasaan bersemangat-tidak bersemangat, perasaan menyenangkan-tidak menyenangkan, perasaan exiting-membosankan dan perasaan santai-membuat tertekan (Beerli \& Martin, 2004a, 2004b; Baloglu \& Love, 2005; Baloglu \& McCleary, 1999).

Dalam kaitan Kota Bandung sebagai salah satu kota tujuan MICE di Indonesia, Kota Bandung sudah memiliki atribut destinasi yang dapat dikembangkan untuk membentuk citra destinasi yang positif. Berbagai keunikan, kekayaan budaya yang dilengkapi dengan berbagai tempat wisata alam dan wisata kuliner di Bandung menjadikannya sebagai salah satu Kota Pariwisata perwakilan Indonesia di dunia internasional yang patut dibanggakan. Bandung sendiri telah terdaftar di World Tourism City Federation (WTCF) bersama 106 kota lainnya di dunia. Bandung juga telah dikukuhkan sebagai tujuan pariwisata dunia pada pertemuan WTCF di Beijing, China.

Atribut dari sebuah destinasi juga merupakan hal yang penting bagi pihak organizer yang akan menyelenggarakan sebuah eventMICE di sebuah tempat atau kota. Atribut destinasi akan berperang sangat penting pada saat organizer menawarkan kegiatan MICE kepada para wisatawan atau pelanggannya. Sebagai contoh, saat seorang perencana pertemuan akan menyelenggarakan sebuah pertemuan, melakukan seleksi terhadap scbuah kota, terlebih dahulu akan mempetimbangkan mengenai atribut-atribut dari sebuah destinasi. Beberapa literatur dan penelitian menyatakan bahwa, pihak organizerakan menilai atribut sebuah destinasi sebelum menyelenggarakan sebuah kegiatan MICE.

Dalam penelitian ini, organizer mengacu kepada anggota Asosiasi Perusahaan Pameran Indonesia (ASPERAPI) yang terdiri dari semua perusahaan di bidang pameran, konvensi dan industri-industri pendukung perusahaan penyelenggara pameran, penyelenggara konvensi, perusahaan kargo dan ekpedisi pameran, kontraktor tenda, pemiliki . ruang pameran, perusahaan pemasok dan industri pendukung. Kementerian Pariwisata dan Ekonomi Kreatif melalui Direktorat Jenderal Pengembangan Destinasi Pariwisata telah melakukan penilaian terhadap enam belas (16) destinasi MICE dengan menggunakan salah satu variabel yakni variabel citra dengan mengguna beberapa indikator yang dibandingakan dengan penelitian ini sebagai berikut:

Tabel

PerbandinQan Indikator Pembentuk Citra

\begin{tabular}{|c|c|c|}
\hline No. & Kemenparekraf & Dalam Penelitian Ini \\
\hline 1 & Pcngalaman Destinasi & Atmosfir \\
\hline 2 & Reputasi & Faktor Sosial dan Politik \\
\hline 3 & Keamanan & Fasilitas Wisata \\
\hline 4 & Kondisi Sosial Politik Kondisi & Sumber daya alam \\
\hline 5 & Kebersihan & Infrastruktur umum \\
\hline 6 & Resiko & Faktor Budaya dan Ekonomi \\
\hline 7 & Pemasaran Destinasi & Faktor afektif \\
\hline
\end{tabular}

Sumber: Hasil Olahan Penulis, 2014. 
Dalam penilaian mengenai citra yang dilakukan oleh Kementerian Pariwisata dan Ekonomi Kreatif melalui Direktorat Jenderal Pengembangan Destinasi Pariwisata Republik Indonesia lebih menekankan pada aspek kognitif, sedangkan dalam penelitian ini, hal yang diteliti mengenai baik aspek kognitif / pengetahuan maupun aspek afektif atau perasaan. Adapun dalam penelitian ini, penulis belum melakukan penilaian mengenai indikator resiko dan pemasaran destinasi. Berdasarkan penelusuran penulis, hingga saat ini belum pernah dilakukan penelitian tentang penilaian peran dari atribut destinasi terhadap pembentukan citra kota Bandung sebagai destinasi MICE, khususnya dari pandangan pihak Anggota ASPERAPI. Adapun pendapat dari peserta pengunjung atau peserta kegiatan MICE tidak dimasukan sebagai pihak yang akan memberikan evaluasi terhadap atribut destinasi MICE yang di Kota Bandung dalam membentuk citra Kota Bandung. Berdasarkan latar bclakang di atas dapat diidentifikasi beberapa masalah, yaitu:

1. Bagaimana tanggapan responden mengenai atribut destinasi Kota Bandung?

2. Bagaimana tanggapan responden mengenai citra destinasi Kota Bandung?

3. Bagaimana tanggapan responden mengenai peranan atribut destinasi Kota Bandung terhadap citra Kota Bandung sebagai destinasi MICE di Indonesia?

Penelitian itu bertujuan untuk melakukan kajian mengenai tanggapan dari pihak anggota ASPERAPI terhadap atribut destinasi Kota Bandung sebagai destinasi MICE di Indonesia; melakukan kajian mengenai tanggapan dari pihak anggota ASPERAPI terhadap citra Kota Bandung sebagai Destinasi MICE di Indonesia; dan melakukan kajian mengenai tanggapan dari pihak anggota ASPERAPI terhadap peranan atribut destinasi Kota Bandung dalam membentuk citra destinasi Kota Bandung sebagai destinasi MICE di Indonesia.

Adapun manfaat dari Penelitian ini adalah menambah pengetahuan penulis dan pembaca mengenai peran dari atribut destinasi dalam meningkatkan citra Kota Bandung sebagai destinasi 1I1ICE1; memberikan masukan kepada para pemangku kepentingan tentang upaya-upaya untuk mengembangkan atribut-atribut destinasi kota Bandung yang bcrpengaruh pada peningkatan citra kota Bandung sebagai destinasi MICE; dan sebagai bahan evaluasi terhadap atribut destinasi MICE Kota Bandung dalam kaitan dengan persaingan sebagai destinasi MICE lainnya di Indonesia.

\section{B. KAJIAN PUSTAKA}

\section{A. Meeting, Incentive, Conference \& Exhibition}

Akronim MICE sudah mulai dikenal secara luas olch masyarakat, menurut Rogers (2003.15), 111/CE merupakan terminologi yang digunakan untuk Meeting, Incentive, Conference dan Exhibition. Dalam hal ini, meeting berarti pertemuan, incentive mengacu kepada perjalanan insetif, conference mengacu kepada kegiatan kenferensi dan exhibition berarti kegiatan pameran. Konsep mengenai bisnis MICE juga diambil dari UU No 10 Tabun 2009 Tentang Kepariwisataan yang menyatakan bahwa usaha penyelenggaraan pertemuan, perjalanan insentif, konferensi, dan pameran adalah usaha yang memberikan jasa bagi suatu pertemuan sekelompok orang, menyelenggarakan perjalanan bagi karyawan dan mitra usaha sebagai imbalan atas prestasinya, serta menyelenggarakan pameran dalam rangka menyebarluaskan informasi dan promosi suatu barang dan jasa yang berskala nasional, regional, dan internasional. 


\section{B. Atribut Destinasi}

Atribut destinasi menjadi salah saw faktor yang menentukan dalam pemilihan atau penentuan sebuah tempat atau lokasi untuk menyelenggarakan sebuah kegiatan MICE. Penentuan atau pemilihan tempat yang memiliki citra yang baik yang didukung oleh atribut destinasi yang baik akan berdampak positif pada penyelenggaraan kegiatan MICE yang ada. Banyak pendapat yang diungkapkan oleh para ahli mengenai atribut destinasi. Menurut Lee and Back (2007) menyimpulkan bahwa atribut destinasi yang diseleksi oleh para organizer antara lain, aksesibilitas, atraksi wisata/hiburan, keterjangkauan, ketersediaan fasilitas, keamanan dan keselamatan, dan kualitas dari pelayanan.

Beberapa ahli telah melakukan penelitian yang berhubungan dengan atribut destinasi, misalnya olch Kim \& Kim (2003), Go \& Govcrs (1999), Kang, Suh \& Jo (2005) dan oleh Lee \& Back (2005). Go \& Govers (1999) lebih menekankan pada aspek- aspek yang lebih umum mengenai aksesibilitas menuju dan selama pelaksaan sebuah kegiatan MICE berlangsung, atraksi wisata yang ada di destinasi MICE, harga yang berhubungan dengan jasa penyelenggaraan $M I C E$, iklim dan lingkungan tempat pelaksanaan sebuah kegiatan MICE, fasilitas utama dan pendukung kegiatan MICE, citra dari destinasi serta aspek pelayanan pada saat sebelum, selama dan setelah kegiatan MICE berlangsung. Sedangkan menurut Kim \& Kim (2003), atribut destinasi bisa dijelaskan secara lebih terperinci mengenai aksesibilitas yang berhubungan dengan kemudahan untuk mencapai destinasi $M I C E$, sistem transportasi darat dan kemudahan untuk mencapai destinasi dengan menggunakan transportasi udara. Atribut daya tarik dan atraksi mengenai kehidupan malam, wisata belanja, sightseeing dan atraksi wisata budaya.

Atribut biaya atau harga mengenai harga yang layak untuk layanan makan dan minum, biaya tur untuk pre, in, post event tour dan tarif sewa kamar untuk penginapan; atribut iklim; atribut fasilitas mengenai fasilitas konvensi dan pameran, ketersediaan peralatan pendukung konferensi dan pameran yang memiliki' teknologi tinggi, ketersediaan kamar hotel, bantuan dari organisasi di tempat penyelenggaraan kegiatan MICE dan perencanan konferensi; atribut destinasi kota mengenai daya tarik area geografisnya; atribut keselamatan dan keamanan bagi penyelengga'ra, peserta atau pengunjung dan atribut pelayanan mengenai kualitas layanan makanan dan minuman, keramahan dan kemarnpuan bcrbahasa asing yang baik dari masyarakat local, kemudahan dalam hal bca cukai, dukungan dari pemerintah, efisiensi dari staf manajerial di pusat konferensi.

Mcnurut Kang, dkk (2005), atribut destinasi terdiri dari aksesibilitas, atraksi wisata, biaya, fasilitas, citra, layanan informasi, keselamatan dan keamanan serta pelayanan. Sedangkan pendapat dari Lee \& Back (2005), atribut destinasi terdiri dari aksesibilitas, atraksi wisata atau hiburan, keterjangkauan mengenai harga dan biaya, lingkungan alam, kctersediaan fasilitas untuk penyelenggaraan MICE, citra destinasi, keselamatan dan keamanan dalam pelaksanaan kegiatan MICE dan kualitas layanan dalam penyelenggaraan MICE.

\section{Citra dan Citra Destinasi}

Dalam pemasaran pariwisata, peran dari citra destinasi sangat dominan dan menjadi elemen yang penting. (Hunt, 1975; Chon, 1991; Echtner and Ritchie, 1991; Aaker, 1996, Gartner, 1996; Kapferer, 1997; Buhalis, 2000, Scoot and Parfitt, 2002, Gartner, 2007; Rial, and Garcia Varela, 2008, dalam Lopes, 2011).

Citra sendiri didefinisikan sebagai "The set of beliefs, ideas, and impressions a person's holds regarding an object. People's attitudes and actions toward an object are highly conditioned by that object's image" (Kotler, 2000). Citra destinasi merupakan hal penting yang dibutuhkan dalam mengembangkan sebuah kota sebagai daerah tujuan wisata, termasuk wisata MICE. Citra destinasi dapat digambarkan sebagai keseluruhan cara pandang dari wisatawan dan pengunjung potensial terhadap keberadaan 
sebuah tempat atau kota. Menurut Dirnanche (2003), citra destinasi sangat bergantung pada faktor lingkungan internal dan eksternal dari pemberi pendapat atau penilaian.

Komponen dari citra destinasi dalam aspek citra kognitif yang diadaptasi dari Chiu \& Ananzeh (2012) terdiri dari pengetahuan dari wisatawan/ organizer mengenai suasana, faktor politik dan sosial, fasilitas untuk wisatawan, sumber daya alam, infrastruktur umum, faktor ekonomi dan budaya (Beerli \& Martin, 2004a, 2004b; Ecthner \& Ritchie, 1993, 2003; McCartney, Butler \& Bennett, 2009, Schneider \& Sonmez, 1999). Sedangkan aspek citra afektif terdiri dari perasaan bersemangat-tidak bersemangat, perasaan menyenangkan-tidak menyenangkan, perasaan exciting-membosankan dan perasaan santaitnembuat tertekan (Beerli \& Martin, 2004a, 2004b; Baloglu \& Love, 2005; Baloglu \& McCleary, 1999).

Penulis mengajukan suatu hipotesis penelitian yang akan diuji dan dibuktikan kebenaranya sebagai berikut: "Atribut destinasi Kota Bandung yang terdiri dari keterjangkauan, atraksi, aksesbilitas, amenitas, aktivitas dan akuntabilitas memiliki peran yang positif untuk membentuk citra kota bandung sebagai Destinasi MICE Di Indonesia".

\section{METODE PENELITIAN}

Dalam penelitian ini, penulis akan menggunakan metode penelitian deskriptif kuantitatif dengan menggunakan teknik analisis regresi berganda. Dalam metode ini Penulis akan mencoba menemukan mengenai peran dari atribut destinasi dalam membentuk komponen kognitif dan afektif dari citra destinasi Kota Bandung sebagai destinasi MICE dan mendeskripsikannya untuk kemudian dianalisis.

Dalam penelitian ini, dengan menggunakan pendekatan teori dan pendapat dari beberapa alli, dalam hal variabel $X$ dan variabel $Y$ dan diadaptasi dari penelitian terdahulu yang pernah dibuat oleh Chiu dan Ananzeh (2012). Variabel X dalam penelitian ini meliputi atribut destinasi MICE yang meliputi Keterjangkauan, Atraksi, Aksesbilitas, Amenitas, Aktivitas dan Akuntabilitas dan Variabel Y adalah Citra Destinasi.

Pengumpulan data-data dalam penelitian ini dilakukan melalui kegiatan penyebaran kuesioner, studi pustaka dan wawancara kepada pihak-pihak yang berkepentingan.

Populasi dalam penelitian ini adalah anggota aktif yang tergabung dalam anggota Asosiasi Perusahaan Pameran Indonesia (ASPERAPI). Adapun pemilihan populasi dan sampel dalam penelitian dari yang terdiri dari anggota ASPERAPI karena anggota ASPERAPI terdiri dari para organizer yang terdiri dari penyelenggara pertemuan, penyelenggara perjalanan insentive, penyelenggara pameran dan penyelenggara konferensi. Adapun anggota yang lain terdiri dari pemangku kepentingan dan penyedia jasa yang berhubungan dalam penyelenggaraan pertemuan, perjalanan insentif, penyelenggara pameran dan konferensi.

Teknik sampling yang digunakan oleh penulis adalah teknik non probability sampling dengan menggunakan teknik convenience.Sample dalam penelitian ini adalah anggota Asosiasi Perusahaan Pameran Indonesia (ASPERAPI). Adapun penentuan jumlah sampel dengan menggunakan rumus Slovin sebagai berikut:

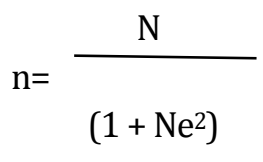

Keterangan :

$\mathrm{n} \quad=\quad$ ukuran sampel

$\mathrm{N} \quad=\quad$ ukuran populasi 
e $\quad=\quad$ Batas Toleransi Kesalahan $=6 \%$ atau tingkat Kesalahan.

Jumlahsampel yang akan di teliti berdasarkan jumlan populasi sebanyak 223 oleh penulis dari rumus Slovin di atas adalah sebagai berikut:

$\mathrm{N}$

$$
\begin{gathered}
n=\left(1+N e^{2}\right) \\
323 \\
n \quad 1+323(0,06)^{2} \\
323 \\
323 \quad 1,1628 \\
\quad-149,34 ; \text { LI } 150
\end{gathered}
$$

Sehingga jumlah sampel yang akan diambil dalam penelitian ini adalah 150 responden.

\section{HASIL DAN ANALISIS}

\section{A. Profil Responden}

Unit bisnis yang diwakili oleh responden pada dasarnya digunakan untuk memberikan penjelasan mengenai aktivitas usaha yang dilakukan oleh Anggota Asperapi. Unit bisnis dimaksud untuk mengidentidikasi ruang lingkup usaha serta karakter usaha yang dimiliki dan juga sebagai pembanding dari masing-masing unit bisnis. Berikut ini adalah gambaran mengenai unit bisnis yang diwakili oleh responden sebagai berikut: organizer sebanyak 118 orang (79 \%), venue owner sebanyak 7 orang (5\%), stand contractor sebanyak 5 orang (3\%), supplier sebanyak 9 orang ( $6 \%$ ), freight forwarder sebanyak 6 orang ( $4 \%$ ) dan entertainment sebanyak 5 (3\%). Adapun berdasarkan data dapat diketahui bahwa mayoritas perusahaan yang diwakili oleh responden sudah berdiri lebih dari 6 yakni sebanyak 50 perusahaan atau $33 \%$, 2-4 tahun sebanyak 47 (31\%), 4-6 tahun sebanyak 43 (29\%), sedangkan yang paling sedikit perusahaan yang berdiri 0-2 tahun yaitu sebanyak 10 perusahaan atau setara dengan $7 \%$.

B. Uji Validitas dan Reliabilitas

Berdasarkan basil olahan mengenai uji validitas dari $\mathrm{X}_{1}$ (keterjangkauan), X2 (atraksi), X3 (aksesibilitas), X4 (amenitas), X5 (aktivitas), X6 (akuntabilitas) dan Y (total citra)diperoleh data bahwa nilai corrected item-total correlation setiap butir pernyataan lebih besar dari 0,30 sehingga dapat disimpulkan bahwa seluruh butir pernyataan pada ketujuh variabel valid dan layak digunakan sebagai alat ukur.Sedangkan nilai reliabilitas butir pernyataan pada kuesioner untuk variabel Y yang sedang diteliti mendapatkan nilai Cronbach's Alpha sebesar 0,879 yang lebih besar dari 0,60 hasil ini menunjukkan bahwa butir kuesioner pada variabel Yandal untuk mengukur variable Y.

C. Tanggapan Responden Terhadap Atribut Destinasi MICE 
Dari 150 responden yang mengembalikan kuesioner diperoleh jawaban mengenai Atribut Destinasi MICE sebagai berikut:

Tabel

Tanggapan Responden Atribut Destinasi MICE

\begin{tabular}{|c|c|c|c|c|c|c|}
\hline \multirow{2}{*}{ Nomor Instrumen } & \multicolumn{5}{|c|}{ Pilihan Jawaban } & \multirow{2}{*}{ Jumlah Skor } \\
\hline & 5 & 4 & 3 & 2 & 1 & \\
\hline 1 & 11 & 95 & 15 & 27 & 2 & 536 \\
\hline 2 & 4 & 103 & 23 & 20 & 0 & 541 \\
\hline 3 & 5 & 101 & 24 & 20 & 0 & 541 \\
\hline 4 & .7 & 106 & 17 & 20 & 0 & 550 \\
\hline 5 & 10 & 98 & 17 & 25 & 0 & 543 \\
\hline 6 & 8 & 119 & 15 & 8 & 0 & 577 \\
\hline 7 & 3 & 88 & 25 & 33 & 1 & 509 \\
\hline 8 & 2 & 77 & 23 & 44 & 4 & 479 \\
\hline 9 & 13 & 101 & 25 & 11 & 0 & 566 \\
\hline 10 & 6 & 118 & 14 & 12 & 0 & 568 \\
\hline 11 & 2 & 119 & 19 & 7 & 3 & 560 \\
\hline 12 & 10 & 100 & 14 & 26 & 0 & 544 \\
\hline 13 & 10 & 100 & 14 & 26 & 0 & 544 \\
\hline 14 & 8 & 119 & 15 & 8 & 0 & 577 \\
\hline 15 & 7 & 117 & 18 & 8 & 0 & 573 \\
\hline 16 & 8 & 118 & 19 & 5 & 0 & 579 \\
\hline 17 & 5 & 122 & 18 & 5 & 0 & 577 \\
\hline 18 & 9 & 99 & 18 & 23 & 1 & 542 \\
\hline 19 & 6 & 104 & 27 & 13 & 0 & 553 \\
\hline 20 & 8 & 115 & 13 & 12 & 2 & 565 \\
\hline 21 & 7 & 118 & 18 & 7 & 0 & 575 \\
\hline Total Skor & 745 & 8948 & 1173 & 720 & 13 & 11599 \\
\hline
\end{tabular}

Si mber: Hasil pengolahan penu is, 2014

Pada Atribut Destinasi MICE dengan jumlah item pernyataan 21 butir dan jumlah responden 150 orang, diperolch total skor sebesar 11599, maka rentang skor setiap kategori ditcntukan sebagai berikut.

$$
(150 \times 21 \times 5)-(150 \times 21 \times 1)
$$

RentangSkorKategori $=$

$=2520$

Jadi panjang interval untuk setiap kategori adalah 2520 sehingga dari jumlah skor tanggapan responden atas 21 butir pernyataan mengenai atribut destinasi MICE diperoleh rentang sebagai berikut. 


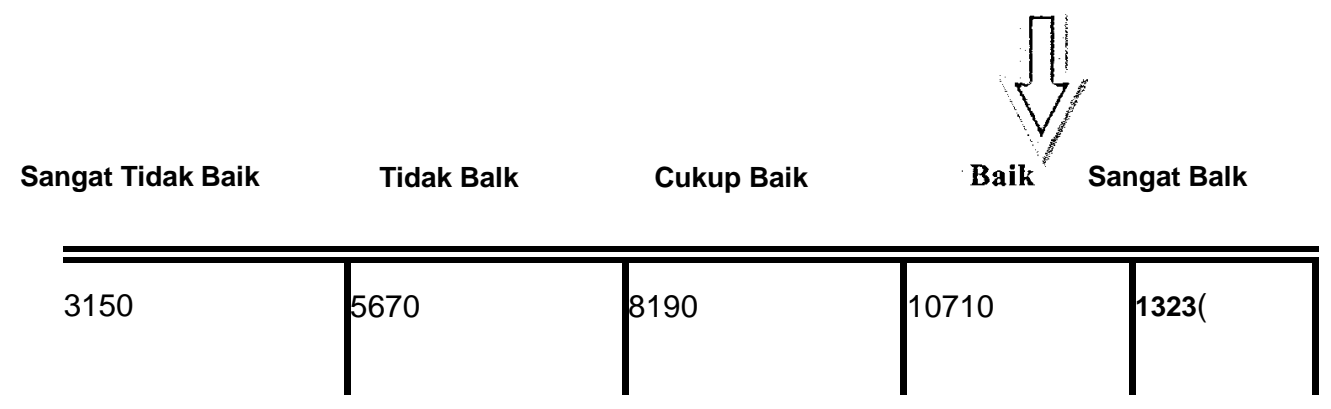

Melalui jumlah skor tanggapan responden dapat diketahui bahwa tanggapan responden tehadap 21 butir pernyataan yang diajukan mengenai atribut destinasi MICE termasuk dalam kategori balk.

\section{Tanggapan Responden Terhadap Citra Kota Bandung}

Dari 150 responden yang mengembalikan kuesioner diperoleh jawaban mengenai citra Kota Bandung sebagai

Tabel

Tanggapan Responden Men enai Citra Kota Bandung

\begin{tabular}{|c|c|c|c|c|c|c|}
\hline \multirow{2}{*}{$\begin{array}{l}\text { Nomor } \\
\text { Instrumen }\end{array}$} & \multicolumn{5}{|c|}{ Pilihan Jawaban } & \multirow{2}{*}{$\begin{array}{l}\text { Jumlah } \\
\text { Skor }\end{array}$} \\
\hline & 5 & 4 & 3 & 2 & 1 & \\
\hline 1 & 3 & 61 & 20 & 55 & 11 & 440 \\
\hline 2 & 6 & 105 & 21 & 16 & 2 & 547 \\
\hline 3 & 5 & 118 & 20 & 7 & 0 & 571 \\
\hline 4 & 4 & 104 & 19 & 22 & 1 & 538 \\
\hline 5 & 9 & 119 & 16 & 6 & 0 & 581 \\
\hline 6 & 4 & 108 & 20 & 18 & 0 & 548 \\
\hline 7 & 2 & 115 & 23 & 7 & 3 & 556 \\
\hline 8 & 7 & 100 & 26 & 16 & 1 & 546 \\
\hline 9 & 4 & 110 & 23 & 13 & 0 & 555 \\
\hline 10 & 7 & 113 & 24 & 6 & 0 & 571 \\
\hline 11 & 2 & 117 & 21 & 7 & 3 & 558 \\
\hline 12 & 11 & 98 & 15 & 26 & 0 & 544 \\
\hline 13 & 9 & 116 & 17 & 8 & 0 & 576 \\
\hline Total Skor & 365 & 5536 & 795 & 414 & 21 & 7131 \\
\hline
\end{tabular}

Sumber: Hasil Olahan Penults, 2014

Pada Citra Kota Bandung dengan jumlah item pernyataan 13 butir dan jumlah responden 150 orang, diperoleh total skor sebesar 7131.

Untuk menghitung rentang skor setiap kategori ditentukan sebagai berikut.

$$
(150 \times 13 \times 5)-(150 \times 13 \times 1)
$$




RentangSkorKategori $=\quad \underline{5} \quad=1560$

Jadi panjang interval untuk setiap kategori adalah 1560 sehingga dari jumlah skor tanggapan responden atas 13 butir pernyataan mengenai citra kota Bandung diperoleh rentang scbagai berikut.

71311159

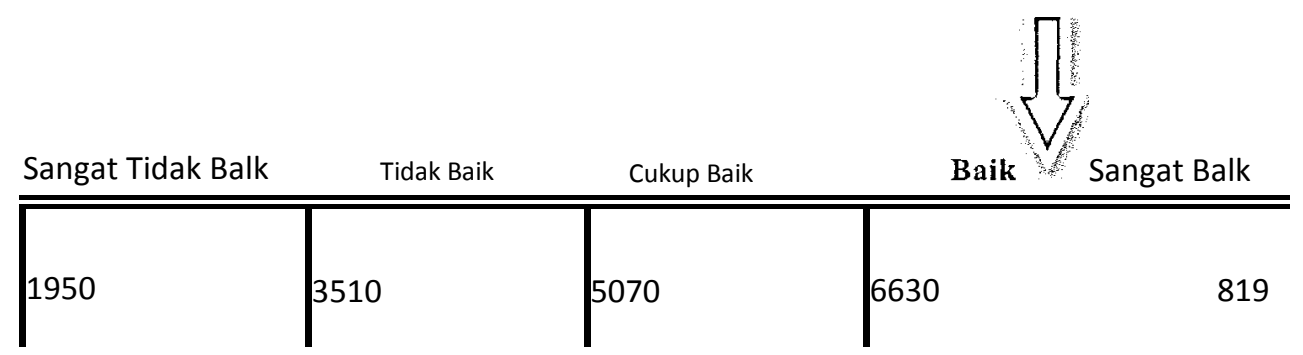

Melalui jumlah skor tanggapan responden dapat diketahui bahwa tanggapan responden tehadap 13 butir pernyataan yang diajukan mengenai citra Kota Bandung termasuk dalam kategori baik.

Berdasarkan analisis deskriptif diperoleh bahwa tanggapan responden yang merupakan Anggota ASPERAPI mengenai atribut destinasi kota Bandung adalah baikdengan jumlah item pernyataan 21 butir dan jumlah responden 150 orang, diperoleh total skor sebesar 11599 dengan rentang skor setiap kategori sebesar 2520.Sedangkan tanggapan responden terhadap citra Kota Bandungdengan jumlah item pernyataan 13 butir dan jumlah responden 150 orang, diperoleh total skor sebesar 7131 dan rentang skor setiap kategori adalah 1560 termasuk dalam kategori balk.

\section{E. Model Regresi Berganda}

Berdasarkan output didapat nilai kontstanta dan koefisien regresi sehingga dapat dibentuk persamaan regresi linier berganda sebagai berikut:

$$
Y=3,495+0,006 X_{r}+0,616 X 2+0,568 X 3+1,762 X 4+0,167 X 5+0,526 X 6
$$

Persamaan di atas dapat diartikan sebagai berikut: $\mathrm{b}_{\mathrm{o}}=3,495$ artinya jika variabel $\mathrm{X}_{\mathrm{i}}, \mathrm{X} 2, \mathrm{X} 3, \mathrm{X} 4, \mathrm{X}$, dan X6 bernilai nol (0), maka variabel $Y$ akan bernilai 3,495 satuan; $b_{1}=0.006$ artinya jika keterjangkauan $\left(\mathrm{X}_{1}\right)$ meningkat sebesar satu satuan dan variabel lainnya konstan, maka variabel citra kota bandung $(\mathrm{Y})$ akan meningkat sebesar 0,006 satuan; $b_{2}=0,616$ artinya jika atraksi $\left(\mathrm{X}_{2}\right)$ meningkat sebesar satu satuan dan variabel lainnya konstan, maka variabel.citra kota Bandung (Y) akan meningkat sebesar 0,616 satuan; $b_{3}=0,568$ artinya jika aksesbilitas $\left(X_{3}\right)$ meningkat sebesar satu satuan dan variabel lainnya konstan, maka variabel citra kota bandung $(\mathrm{Y})$ akan meningkat sebesar 0,568 satuan; $\mathrm{b}_{4}=1,762$ artinya jika amenitas $\left(\mathrm{X}_{4}\right)$ meningkat sebesar satu satuan dan variabel lainnya konstan, maka variabel citra kota bandung $(\mathrm{Y})$ akan meningkat sebesar 1,762 satuan; $b_{5}=0,167$ artinya jika aktivitas $\left(\mathrm{X}_{5}\right)$ meningkat sebesar satu satuan dan variabel lainnya konstan, maka variabel citra kota bandung $(Y)$ akan meningkat sebesar 0,167 satuan.; $b_{6}=0,526$ artinya jika 
akuntabilitas $\left(\mathrm{X}_{6}\right)$ meningkat sebesar satu satuan dan variabel lainnya konstan, maka variabel citra kota bandung $(\mathrm{Y})$ akan meningkat sebesar 0,526 satuan.

\section{F. Uji Hipotesis}

Berdasarkan basil Uji T, atribut destinasi keterjangkauan dengan nillai $p$-value $=0,945<-0,05$ dan atribut destinasi aktivitas dengan nillai $p$-value $=0,227>0,05$, secara parsial tidak berpengaruh signifikan terhadap pembentukan citra Kota Bandung sebagai destinasi MICE di Indonesia. Sedangkan atribut destinasi atraksi wisata dengan nillai $p$-value $=0,000<0,05$, aksesbilitas dengan nillai $p$-value $=0,000>0,05$, amenitas dengan nillai $p$-value $=0,000>0,05$ dan akuntabilitas dengan nillai $p$-value $=0,000>0,05$, secara parsial berpengaruh signifikan terhadap pembentukan citra Kota Bandung.

Secara simultan keterjangkauan, atraksi, aksesbilitas, amenitas, aktivitas dan akuntabilitas berpengaruh terhadap pembentukan citra Kota Bandung sebagai destinasi MICE. Adapun berdasarkan basil penelitian empiris di lapangan diperoleh informasi bahwa keterjangkauan, atraksi, aksesbilitas, amenitas, aktivitas dan akuntabilitas berpengaruh terhadap pembentukan citra Kota Bandung sebagai destinasi MICE sebesar 88,4\%. Sedangkan sisanya sebesar 11,6\% dipengaruhi oleh faktor lain yang tidak diamati di dalam pcnelitian ini.

\section{E. SIMPULAN DAN SARAN}

\section{Simpulan}

Berdasarkan basil penelitian dan pembahasan pada bab sebelumnya, penulis dapat mengambil beberapa kesimpulan bahwa berdasarkan analisis deskriptif diperoleh bahwa tanggapan responden yang merupakan Anggota ASPERAPI mengenai atribut destinasi kota Bandung adalah baik dan tanggapan responden yang merupakan Anggota ASPERAPI mengenai citra Kota Bandung adalah baik.

Adapun hasil Uji $\mathrm{T}$ diperoleh hasil dan gambaran bahwa atribut destinasi berupa atraksi, aksesbilitas, amenitas, akuntabilitas secara parsial berpengaruh signifikan terhadap pembentukan citra Kota Bandung, sedangkan atribut destinasi keterjangkauan dan aktivitas secara parsial tidak berpengaruh signifikan terhadap pembentukan citra Kota Bandung. Atribut destinasi berupa keterjangkauan dalam hal harga dan aktivitas yang tidak berpengaruh secara parsial terhadap citra Kota Bandung sebagai destinasi MICE di Indonesia didukung oleh adanya pendapat bahwa wisatawan MICE umumnya diklasifikasikan 'quality tourist' yang cenderung tinggal lebih lama dan menghabiskan uang lebih banyak dad wisatawan biasa danpengeluaran wisatawan MICE adalah tujuh kali lipat lcbih banyak dari wisatawan biasa.

Adapun besaran pengaruh dari atribut keterjangkauan, atraksi, aksesbilitas, amenitas, aktivitas dan akuntabilitas terhadap pembentukan citra Kota Bandung sebagai destinasi MICE scbesar $88,4 \%$. Adapun faktor-faktor lain yang berpengaruh terhadap pembentukan citra sebagaimana yang diadopsi oleh Kementerian Pariwisata dan Ekonomi Krcatif melalui Direktorat Jenderal Pengembangan Destinasi Pariwisata Republik Indonesia dalam penelitian terdahulu adalah mengenai indikator resiko dan pemasaran destinasi.

Besarnya pengaruh dad atribut destinasi terhadap pembetukan citra destinasi Kota Bandung sebagai destinasi MICE di Indonesia memberikan makna bahwa Kota Bandung akan lebih sukses dalam mengelola bisnis $M I C E$ apabila pengelolaan atribut destinasi yang baik yang berdampak pada terciptanya Kota Bandung sebagai salah satu destinasi MICE favorit Indonesia. Dengan kata lain, meningkatnya citra Kota Bandung yang dipengaruhi oleh pemenuhan atribut destinasi juga akan menaikkan peringkat destinasi MICE dari peringkat ke-6 dari 16 destinasi MICE di Indonesia. Berdasarkan data dari MICE Center (2013) , peringkat Kota Bandung sesuai penilaian mandiri dan penilaian dari para expert di bidang MICE 
berada di peringkat ke-6 di bawah Bali, Jakarta, Surabaya, Yogyakarta dan Makassar. Hal ini juga diperkuat oleh pendapat yang disampaikan oleh Go and Govers ( 2000) bahwa terkait efek globalisasi, persaingan bisnis MICE tclah bergeser dari persaingan antar perusahaan menjadi persaingan antar destinasi.

\section{Saran}

Ada beberapa saran yang bisa di berikan oleh penulis kepada pemerintah kota Bandung untuk mempertahankan dan mcningkatkan atribut destinasi agar Citra Kota Bandung sebagai destinasi MICE di mata organizer semakin meningkat. Atribut Keterjangkauan dalam hal harga dengan langkah memberikan insetif pajak dan subsidi kepada para organizer yang menyelenggarakan kegiatan MICE di Kota Bandung dan bekerja sama dengan pihak swasta untuk menyediakan fasilitas gedung konvensi. Atribut atraksi wisata dengan memperhatikan aspek-aspek originalitas, keotentikan atraksi wisata. Atribut aksesbilitas bahwa perhatian terhadap kemudahan untuk mencapai Kota Bandung tidak mengurangi perhatian terhadap kemudahan dan kelancaran untuk mencapai lokasi penyelenggaraan MICE di Kota Bandung.upaya-upaya untuk mengurangi kemacetan di Kota Bandung perlu ditingkatkan. Atribut amenitas yang merupakan aspek fasilitas yang dibutuhkan oleh organizer maka pembangunan fasilitas MICE dapat mengadopsi konsep facility package. Artinya dalam membangun fasilitas MICE diupayakan dilakukan secara terpusat di dalam suatu kawasan. Rencana pembangunan pusat MICE di Kawasan Gedebage diupayakan menggunakan pendekatan ini. Atribut aktivitas yang berhubungan dengan aktivitas rekreasi sebelum, selama dan setelah kegiatan MICE maka direkomendasikan untuk melakukan kerja sama antara organizer dengan tour organizer untuk menemukan, menciptakan dan melakukan inovasi atas paket-paket tur yang disesuaikan kebutuhan wisatawan MICE yang disebut sebagai quality tourist.Atribut akuntabilitas menyangkut dua hal yakni layanan kesehatan, bea cukai, karantina dan imigrasi dan sumber daya manusia di bidang penyelenggara MICE yang berkualitas dan berkompeten.

Sehubungan dengan layanan kesehatan, bea cukai, karantina dan imigrasi maka direkomendasikan kepada Pemerintah Kota Bandung bekerja sama dengan organizer untuk membuatkan layanan khusus dan kepada wisatawan MICE. Mengenai penyediaan sumber daya manusia di bidang penyelenggaraan MICE yang berkualitas dan berkompeten, maka direkomendasikan kepada pihak Pemerintah Kota Bandung dan pihak organizer sccara bersama-sama untuk membuat program yang berhubungan dengan pclatihan tentang hospitalitas, standar layanan internasional, manajemen kualitas; menyelenggarakan sertifikasi profesi di Bidang MICE, Uji Kompetensi di bidang MICE, aktif memberikan masukan kepada lembaga pendidikan dalam hal penyusunan kurikulum di bidang MICE, program mentoring, pemberian pengalaman kerja dan atau praktekk kerja nyata kepada mahasiswa MICE.

\section{DAFTAR REFERENSI}

Akhyaruddin, SE, M.Sc. 2013. Pemetaan 16 Destinasi MICE.Jakarta: Seminar MICE Outlook. 5-6 Desember 2013.

Allen, Judy. 2009. Event Planning. $2^{\text {nd }}$ Edition. Canada: John Wiley \& Sons, Inc.

Allen, Johhny et all. 2011. Festival \& Special Event Management. Milton: John Wiley \& Sons Australia Ltd.

Ant/hrb. 2012. Bandung Semakin Diminati Sebagai Destinasi Wisata. Investordaily.com. 9 November.

Chiu, Lim Khong and Ananzeh, Omar A. 2012. The Role of MICE Destination Attribute On Forming Jordan Touristic Image. Journals of SAVAP International: 2012. 
Crouch, G. dan Louviere, J. 2004. Convention Site Selection: Determinants Of Destination Choice In The Australian Domestic Conventions Sector.Canbera: CRC for Sustainable Tourism.

Dimanche, F. (2003). Destination image evaluation: Part I. Eclipse [On-line], 9/10. Available: http://www,moonshine.es/ECLIPSE.

Echtner, Charlotte M. and Ritchie, J.R. Brent. 2013. The Meaning and Measurement of Destination Image. The Journal of Tourism Studies.

Gartner, W.C.1993. Image Formation Process. Journal of Travel and Tourism Marketing.

Herdiyan. 2011. Handrio Utomo Terobsesi Jadikan Bandung Kiblat MICE Dunia. Bandung.bisnis.com. 19 Agustus.

Kesrul, M. 2004. Meeting, Incentive Trip, Conference, Exhibition Jakarta: Graha Ilmu Kim, H, S.L. (2003). Motion Pictures Impact on Destination Image. Annals of Tourism. Konecnik, M. 2004.Evaluating Slovenia's Image as a Tourism Destination: A Self Analysis Process towards Building a Destination Brand.Journsl of Brand Management.

Lee, M.J. \& Back, K. (2007). Effects of Destination Image on Meeting Paticipation Intention: Empirical Findings from a Professional Association and Its Annual Convention. The Service Industries Journal.

Leo, Sutanto.2013.Kiat Jitu Menulis Skripsi, Tesis, dan Disertasi.Jakarta: Erlangga

Mair, Judith. 2009. Conferences and Conventions: A Research Perspective. New York: Routledge.

Pemerintah Kota Bandung. 2012. Rencana Induk_Pengembangan Pariwisata Daerah Kota Bandung Tabun 2012-2015 (RIPPDA 2012-2025). Bandung.

Pemerintah Republik Indonesia. 2009. Undang-undang No. 10 Tahun 2009 Tentang Kepariwisataan. Jakarta

Richardson S. S \& Lee, C.K.S \& Klenosky, D.B. 2002.The"Pull" of Tourist Destination: a Means-End Investigation.Journal of Travel Research.

Ritchie, J.R. Brent and Crouch, Geoffrey I. 2003. The Competitive Destination.A Sustainable Tourism Perspective. Melbourne: CABI Publishing.

Rogers, Tony. 2004. Conferences and Conventions: A Global Industry. Second Edition. Oxford: Butterworth Heinemann.

Rustandi, Ageng. 2013. Untuk MICE Secara Nasional, Jabar Sumbang Rp.9 T. Inilahkoran.com. 10 April.

Site. 1998. Definition of Incentive Travel. Diakses pada tanggal 23 Oktober 2013 dart http://www.sito-germany.de/40639.html

Sugiyono. 2007. Metode Penelitian Bisnis. Bandung: CV Alfabeta

Swarbrooke, John and Horner, Susan. 20.01. Business of Travel and Tourism. Oxford: ButterworthHeinemann

UNWT0. 2012. MICE Industry: An Asia Pacific Perspective.Madrid: WTO.

UFI. 2011. The 2011 World Map of Exhitibion Venues - December 2011. http://www.ufi.org/Public/Default.aspx?Clef $\quad$ SITESMAPS=142\&Clef_SITESMA PS=144\#worldmap

Whitfield, J., Diokko, L. D. A. N., Webber, D. dan Zhang, L. 2012. Attracting convention and exhibition attendance to complex mice venues: Emerging data from Monaco .International Journal of Tourism Research.

Wiidc, Simon John. 2010.A holistic investigation into principal attributes contributing to the tourism destination at varying stages of development. l'hcses. EPublications. Southern Cross University. 